\title{
Morphophysiology of tropical grasses under different water supply in two growing seasons: II. BRS Massai and BRS Tamani grasses
}

\section{Morfofisiologia de gramíneas tropicais sob diferentes regimes hídricos em duas estações de crescimento: II. capins BRS Massai e BRS Tamani}

\author{
Samuel Rocha Maranhão'; Roberto Cláudio Fernandes Franco Pompeu²; \\ Ricardo Alves de Araújo ${ }^{3 *}$; Marcos Neves Lopes ${ }^{4}$; Magno José Duarte Cândido \\ Henrique Antunes de Souza6; Ana Clara Rodrigues Cavalcante2; \\ Renato Gomes Fontinele7; Marcos Cláudio Pinheiro Rogério²
}

\section{Highlights}

Massai BRS grass and Tamani BRS has potential for cultivation in the semiarid region.

In the dry season the grass-tamani has greater production of leaf biomass.

The depth of $90 \%$ favors the morphophysiological characteristics of both cultivars.

\begin{abstract}
This study aimed to evaluate the physiological parameters and the biomass flow and structural characteristics of BRS Massai and BRS Tamani grasses under different irrigation conditions. The rating of gas exchange, biomass flow and structural characteristics were performed in dry periods and dry/rainy season, under the water supply of 30; 60; 90 and $120 \%$ of the reference evapotranspiration (ETo). The experimental design was completely randomized in a factorial arrangement $4 \times 2$ (water supply and grass). The experiment was conducted in pots with capacity for $7.5 \mathrm{dm}^{3}$, using as substrate layer of 0-0.2 m soil. There was no effect

1 Discente do Curso de Doutorado do Programa de Doutorado Integrado em Zootecnia, PDIZ, Departamento de Zootecnia, Universidade Federal do Ceará, UFC, Fortaleza, CE, Brasil. E-mail: samuel zootec@hotmail.com

2 Pesquisadores, Empresa Brasileira de Pesquisa Agropecuária, EMBRAPA, Centro Nacional de Pesquisa de Caprinos, Sobral, CE, Brasil. E-mail: roberto.pompeu@embrapa.br; ana.clara@embrapa.br; marcos.claudio@embrapa.br

3 Prof., Universidade Estadual do Maranhão, UEMA, Itapecuru Mirim, MA, Brasil. E-mail: ricardo_zoo@hotmail.com

${ }^{4}$ Prof., Instituto Federal de Educação, Ciência e Tecnologia do Piauí, IFPI, Valença do Piauí, PI, Brasil. E-mail: nevesvv@ yahoo.com.br

5 Prof., Universidade Federal do Ceará, UFC, Fortaleza, CE, Brasil. E-mail: mjdcandido@gmail.com

${ }^{6}$ Pesquisador, EMBRAPA, Centro de Pesquisa Agropecuária do Meio-Norte, Teresina, PI, Brasil. E-mail: henrique.souza@ embrapa.br

7 M.e em Zootecnia, Universidade Estadual Vale do Acaraú, UVA, Sobral, CE, Brasil. E-mail: renato.gomes.fontinele@ gmail.com

* Author for correspondence
\end{abstract}

Received: Apr. 27, 2020 - Approved: Oct. 20, 2020 
$(P<0.05)$ between the gas exchange in the dry period, having the largest growing parameters of irrigation schemes. In the transition period of dry/rainy, we observed a reversal behavior in relation to the dry period, showing a rapid recovery of grasses under the minor water supply. It was observed quadratic behavior to concentrations of $\mathrm{CO}_{2}$ in the leaf mesophilic (Ci) with maximum point to the BRS Massai grass and minimum point to the BRS Tamani grass, where the major and minor Ci were 119 and 48 ppm in the water supply of 107 and $35 \%$ of ETo, respectively. In relation to the biomass flow, the BRS Tamani grass presented greater stem elongation rate and leaf senescence rate in relation to BRS Massai in both periods assessed. In the dry period, we observed a higher biomass production of green leaf blades in the BRS Tamani grass, while in the transition dry/rainy season, the results for this variable were similar, and at the same time that observed higher accumulation of green culm biomass to the BRS Tamani grass, which certainly affected its structure. It is concluded that the application of a minimum daily water supply of $30 \%$ of ETo allows the maintenance of BRS Massai and BRS Tamani grasses without incurring the death of tillers and reduction of regrowth vigor, whereas the water supply of $90 \%$ of ETo favors the morphophysiological characteristics, especially of BRS Tamani grass.

Key words: Water supply. Edaphoclimatic conditions. Megathyrsus maximus.

\section{Resumo}

Objetivou-se avaliar os parâmetros fisiológicos, as características morfogênicas e estruturais dos capins BRS Massai e BRS Tamani sob diferentes condições hídricas. As avaliações de trocas gasosas, do fluxo de biomassa e das características estruturais foram realizadas nos períodos seco e de transição seca/ águas, sob os regimes de lâminas de irrigação de 30; 60; 90 e 120\% da evapotranspiração de referência (ETo). Utilizou-se o delineamento inteiramente casualizado em arranjo fatorial 4x2 (lâminas de irrigação e gramíneas). O experimento foi conduzido em vasos com capacidade para 7,5 $\mathrm{dm}^{3}$, utilizando como substrato a camada de 0-0,2 $\mathrm{m}$ do solo. Houve efeito $(P<0,05)$ entre as trocas gasosas no período seco, onde os crescentes regimes de irrigação proporcionaram melhores resultados. No período de transição seco/chuvoso observou-se uma inversão de comportamento em relação ao período seco, evidenciando rápida recuperação das gramíneas sob os menores tratamentos de irrigação. Observou-se comportamento quadrático para variável concentrações de $\mathrm{CO}_{2}$ no mesófilo foliar (Ci), com ponto de máximo para o capimmassai e de mínimo para o capim-tamani, onde as maiores e menores Ci de 119 e 48 ppm nas lâminas de irrigação de 107 e 35\% da ETo, respectivamente. No tocante ao fluxo de biomassa, o capim-tamani apresentou maior taxa de alongamento das hastes e de senescência foliar em relação a cultivar BRS Massai em ambos os períodos avaliados. No período seco, observou-se maior produção de biomassa de lâminas foliares verde no capim-tamani, enquanto que no período de transição seca/águas, os resultados para esta variável foram semelhantes, ao mesmo tempo em que se observa maior acúmulo de biomassa de colmo verde no capim-tamani, o que afetou sua estrutura. Conclui-se que a aplicação de uma lâmina mínima diária de $30 \%$ da ETo possibilita a manutenção das gramíneas BRS Massai e BRS Tamani sem incorrer em morte de perfilhos e redução do vigor de rebrotação, ao passo que a lâmina de $90 \%$ da ETo favorece as características morfofisiológicas, em especial do capim-tamani.

Palavras-chave: Lâminas de irrigação. Condições edafoclimáticas. Megathyrsus maximus. 


\section{Introduction}

In Brazil, there are numerous areas temporarily or continuously subjected to drought and, or, flooding. At the same time, small intervals without rain are frequent during the rainy season, in the main ruminant producing regions of Brazil. Drought interferes in water relations, physiology and morphology of forage plants to the point of causing water stress, which, depending on its magnitude, can severely limit forage production and even the survival of the species. Thus, seasonality in rainfall distribution, associated with poor management of water resources and the choice of unadopted forage genotypes, are the main causes of failure and low productivity of cultivated pastures (Maranhão et al., 2019; Dantas, Faria, Santos, Dalri, \& Palaretti, 2016).

It should also be emphasized that the irrational use of irrigation water goes beyond the way it is stored. In the vast majority of irrigated pasture areas, their use is empirically, so that a large amount of water is lost by evaporation and/or leaching, causing, in many cases, nutrient perpetration and salinization (Silva, Carneiro, Furtado, Lopes, \& Braga, 2020). Thus, in view of the water scarcity and the misuse of this resource, it is necessary to use technologies that minimize such losses and provide more rational management of irrigation water.

In Semiarid regions, high evapotranspiration is a limiting factor for plant biomass production (Gomes et al., 2018). Even with water for irrigation, the use of more adapted genotypes is an indispensable condition for the best use of this resource, so that the use of a minimum irrigation depth to maintain the forage crop may be a relevant alternative in view of a possible water limitation due to climatic factors. Soil is another major factor for moisture retention for crops, so that it should be considered when choosing the forage that best is appropriate, especially regarding texture.

In recent decades, new forages adapted to the most diverse edaphoclimatic conditions have been launched by the research centers, however these studies are mainly focused on the Central Region of Brazil (Souza \& Martuscello, 2017), with incipient studies of this nature in the Brazilian Semiarid region, particularly (Maranhão et al., 2019). There is a consensus in the classical literature that forage plants develop certain mechanisms of adaptation to drought, such as stomatal closure (Monteiro, Cruz, Nardin, \& Santos, 2014), osmotic adjustment (Marijuan \& Bosch, 2013), adjustment of the cell wall (Barros et al., 2019), production of smaller leaves (Santos et al., 2013), reduction of leaf area (Maranhão et al., 2019) and increase in root density and depth (Pezzopane et al., 2015), however in view of the launch of new species on the market, there is a need to assess the mechanisms of tolerance to water deficit.

In view of the above, the objective was to evaluate the physiological parameters, morphogenic and structural characteristics of BRS Massai and BRS Tamani weeds, submitted to different water supplies.

\section{Material and Methods}

The experiment was conducted in the municipality of Sobral, Ceará, at Fazenda Três Lagoas ( $3^{\circ} 45^{\prime} 00.77^{\prime \prime} \mathrm{S}$ and $\left.40^{\circ} 20^{\prime} 38.55^{\prime \prime} \mathrm{O}\right)$, belonging to Embrapa Goats and Sheep. The climate is Bsh type, semi-arid hot, with rainfall in the summer-autumn period, precipitation 
and average temperatures of $912.0 \mathrm{~mm}$ and $28.5^{\circ} \mathrm{C}$, respectively. The average temperature and precipitation data (Fundação Cearense de
Meteorologia e Recursos Hídricos [FUNCEME], 2016) are shown in Figure 1.

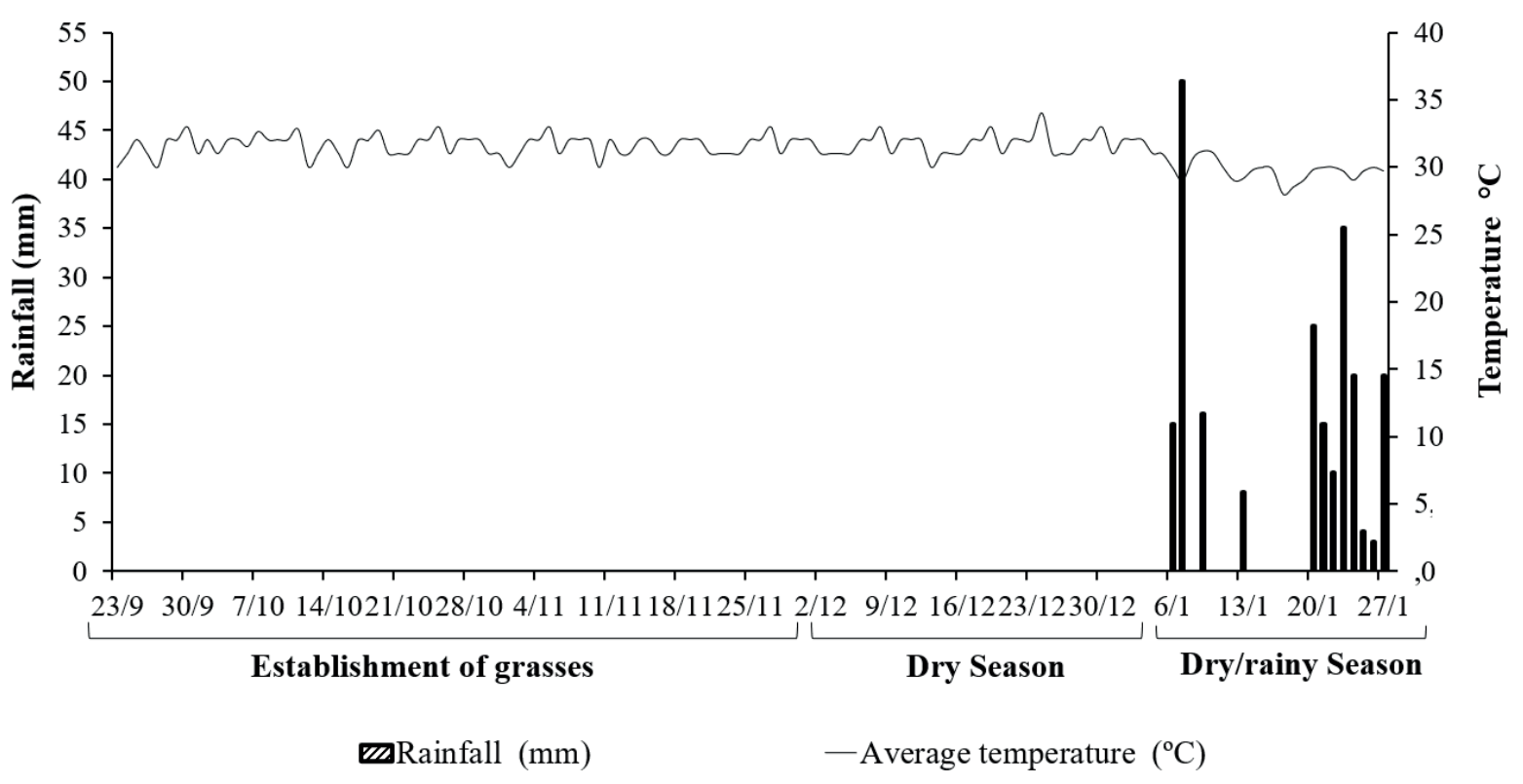

Figure 1. Precipitation $(\mathrm{mm})$ and average temperature $\left({ }^{\circ} \mathrm{C}\right)$ recorded during the experimental period.

The test was conducted in pots with a capacity of $7.5 \mathrm{dm}^{3}$, using as a substrate the layer of 0-0.2 $\mathrm{m}$ of a soil of the type Argisol Red Yellow (H. G. Santos et al., 2018) with the following chemical and granulometric characteristics: $\mathrm{pH}\left(\right.$ in $\left._{2} \mathrm{O}\right)=5.7 ; \mathrm{O} . \mathrm{M} .\left(\mathrm{g} \mathrm{dm}^{-3}\right)=$ 5; $\mathrm{P}\left(\mathrm{mg} \mathrm{dm}^{-3}\right)=4 ; \mathrm{K}\left(\mathrm{mg} \mathrm{dm}^{-3}\right)=23 ; \mathrm{Ca}(\mathrm{mmolc}$ $\left.\mathrm{dm}^{-3}\right)=14 ; \mathrm{Mg}\left(\mathrm{mmolc} \mathrm{dm}^{-3}\right)=2 ; \mathrm{H}+\mathrm{Al}(\mathrm{mmolc}$ $\left.\mathrm{dm}^{-3}\right)=18 ; \mathrm{Al}\left(\mathrm{mmolc} \mathrm{dm}^{-3}\right)=0 ; \mathrm{SB}\left(\mathrm{mmolc} \mathrm{dm}^{-3}\right)$ $=17 ; \mathrm{CEC}(\mathrm{mmolc} \mathrm{dm}-3)=35 ; \mathrm{V}(\%)=48 ; \mathrm{S}(\mathrm{mg}$ $\left.\mathrm{dm}^{-3}\right)=3 ; \mathrm{Na}\left(\mathrm{mg} \mathrm{dm}^{-3}\right)=2 ; \mathrm{B}\left(\mathrm{mg} \mathrm{dm}^{-3}\right)=0.12 ;$ $\mathrm{Cu}\left(\mathrm{mg} \mathrm{dm}^{-3}\right)=0.2 ; \mathrm{Fe}\left(\mathrm{mg} \mathrm{dm}^{-3}\right)=5 ; \mathrm{Mn}(\mathrm{mg}$ $\left.\mathrm{dm}^{-3}\right)=6 ; \mathrm{Zn}\left(\mathrm{mg} \mathrm{dm}^{-3}\right)=0.9 ;$ Clay $\left(\mathrm{g} \mathrm{kg}^{-1}\right)=84$; Silt $\left(\mathrm{g} \mathrm{kg}^{-1}\right)=16$; Coarse sand $\left(\mathrm{g} \mathrm{kg}^{-1}\right)=840$; Fine sand $\left(\mathrm{g} \mathrm{kg}^{-1}\right)=60$. After cleaning and removing the soil, the soil was corrected for $\mathrm{P}\left(15 \mathrm{mg} \mathrm{dm}^{-}\right.$ $\left.{ }^{3}\right)$ and $\mathrm{K}\left(10 \mathrm{mg} \mathrm{dm}^{-3}\right)$, with no need for liming (base saturation $)=48 \%)$. The pots were placed on benches at field level.

Two tropical forage grasses of the species Megathyrsus maximus (Sin. Panicum maximum), cultivars BRS Massai and BRS Tamani. A completely randomized design was used in a factorial scheme of $4 \times 2$ (four irrigation depths and two grasses) with 15 replications (tillers), three per pot. Ten days after seedling emergence, thinning was performed for the permanence of three tillers and $15 \mathrm{mg} \mathrm{dm}^{3}$ of nitrogen $(0.25 \mathrm{~g}$ of urea) per pot was applied. In this phase were evaluated, the irrigation depth used $(100 \%$ of the reference evapotranspiration - ETo) was obtained by collecting the daily evaporation of the Class ' $A$ ' Tank for subsequent estimation of 
ETo, according to the methodology described by Maranhão et al. (2019).

The grasses (BRS Massai and BRS Tamani) were treated with four irrigation depths: $30 ; 60 ; 90$ and $120 \%$ of reference evapotranspiration (ETo) (Figure 2). To estimate the end of the growth period, the criterion was the stabilization of the number of live leaves per tiller (LLT) under the treatment with the depth of $90 \%$ of ETo during the dry period, taking into account the water volume that is closest to that used in the establishment phase $(100 \%$ of ETo). For irrigation management, the same procedures were adopted in the establishment phase. Nitrogen fertilization ( $15 \mathrm{mg}$ of $\mathrm{N} \mathrm{dm}^{-3}$ of soil) was applied immediately after cutting the grasses.

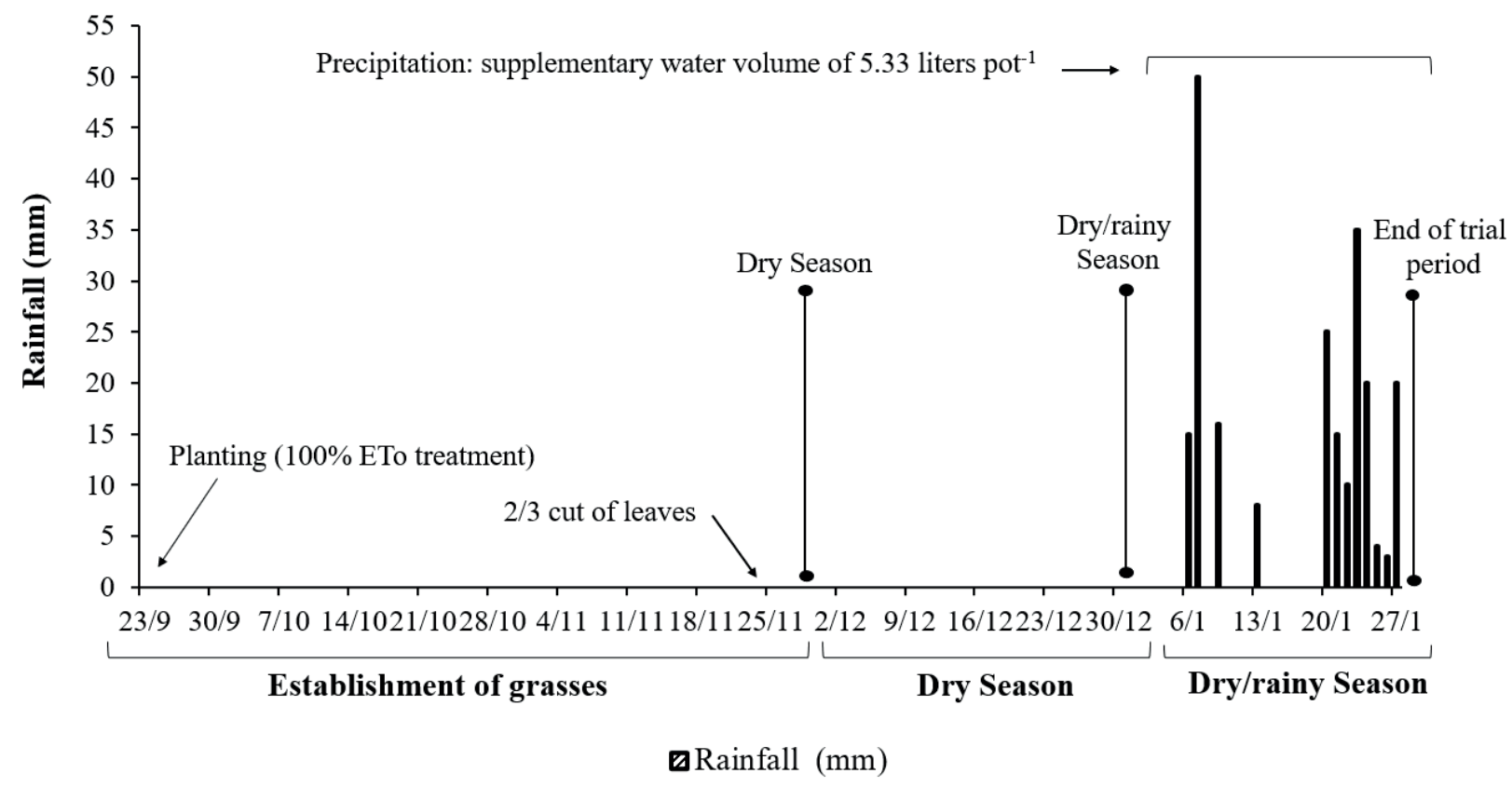

Figure 2. Timeline with the main activities developed during the experimental period.

Gas exchange evaluations were performed using the infrared $\mathrm{CO}_{2}$ analyzer, IRGA model LCpro-SD (ADC Bioscientific Ltd Hoddesdon, Hertfordshire, UK). The readings during the treatment with the irrigation depth regime were performed on the 10th day after cutting corresponding to the beginning of each growth cycle. The variables, leaf temperature $\left(\mathrm{LT},{ }^{\circ} \mathrm{C}\right)$, internal concentration of $\mathrm{CO}_{2}$ in the leaf $(\mathrm{Ci}, \mathrm{ppm})$, leaf transpiration rate $\left(\mathrm{E}, \mathrm{mol} \mathrm{m}^{-2}\right.$ $\left.\mathrm{s}^{-1}\right)$, stomatic conductance (gs, $\mathrm{mmol} \mathrm{m}^{-2} \mathrm{~s}^{-1}$ ) and leaf photosynthesis rate $\left(A, \mu \mathrm{mol} \mathrm{m} \mathrm{m}^{-2} \mathrm{~s}^{-1}\right)$ were analyzed.

For the evaluation of biomass flow, three tillers per pot were selected and identified with telephone wire rings of different colors. For each identified tiller, the length of the leaf blade was measured from the exposed lip, when the leaf was completely expanded, and the leaf lip immediately lower, when it was an expanding leaf. The total length of the leaf is divided into green fraction and dead fraction, the latter 
being obtained by difference of total length. Stem height was obtained by measuring the length of the ligule of the last fully expanded leaf relative to the soil. Evaluations were carried out every three days.

By monitoring the biomass flow of forages, it was possible to estimate the rate of leaf elongation $\left(\mathrm{RLE}=\mathrm{cm}\right.$ tiller $^{-1}$ day $\left.^{-1}\right)$, stems $\left(\right.$ RSE $=\mathrm{cm}_{\text {tiller }}{ }^{-1}$ day $\left.^{-1}\right)$, leaf senescence (LS $=\mathrm{cm}$ tiller $^{-1}$ day $^{-1}$ ) and phyllochron, a variable that shows the time required, in days, until complete leaf expansion. At the end of each growth period, the following measurements were performed before the cut: number of live leaves per tiller (NLL) and population density of tiller (PDT) and dead material (DM).

The height of the plants was measured with the aid of a ruler, being taken five heights randomly in each repetition (pot) starting from the soil until the meeting of the ruler with the curvature of the leaves of the plants. The number of live leaves per tillers obtained by counting the leaves of five byes randomly for each repetition (pot). For truncated leaves resulting from previous cycles and leaves in emergency, that is, those that did not present the exposure of the ligule were considered the value of 0.5 leaves.

The population density of tillers was counted in each pot, at each evaluation interval. The angle of inclination of the tiller (AN), which is achieved by measuring the length of the stems vertically from the ligule of the last expanded leaf in relation to the soil and, horizontally, corresponding to the length of the insertion of the grass at the height of the last exposed gullet was measured. Immediately after these measurements, 2/3 of the grass leaves were cut. The harvested material was weighed and divided into leaf, stem and dead material to determine the green leaf blade biomass
(GLBB) and green stem biomass (GSB). After fractionation, the material was weighed, placed in paper bags, dried in the oven at $55^{\circ} \mathrm{C}$ until constant weight and weighed again.

The water use efficiency for the production of green forage biomass (WUEGFB), which considers the fractions leaf and stem, was obtained by the ratio between green forage biomass ( $\mathrm{g} \mathrm{pot}^{-1}$ ) and volume of water corresponding to each treatment with irrigation depth.

The data were analyzed by variance analysis, mean comparison test and regression analysis. For the purpose of irrigation depth, regression analysis was performed based on linear, quadratic and cubic models. The means were compared by the Tukey Test at the level of $5 \%$ probability and the interaction was deployed when significant to $5 \%$ probability by the $\mathrm{F}$ test. As an aid tool in the statistical analyses, the Software SISVAR, 2011 was used.

\section{Results and Discussion}

Therewasno effect $(P>0.05)$ of irrigation depths and grasses on gas exchange during the dry period (Table 1). The isolated effect of Massai grass differed from that of Tamani grass, with the former showing a higher $\mathrm{Ci}$. When analyzing the isolated effect of irrigation depths, a quadratic behavior with a minimum point was observed in $\mathrm{LT}$ and $\mathrm{Ci}\left(43.1^{\circ} \mathrm{C}\right.$ and $55.8 \mathrm{ppm}$ estimated in the irrigation depths of $104 \%$ and $46 \%$ ETo, respectively), a quadratic behavior with a maximum point was observed in $E$ and $A\left(6.08 \mathrm{~mol} \mathrm{~m}^{-2} \mathrm{~s}^{-1}\right.$ and $18.22 \mu \mathrm{mol} \mathrm{m}^{-2}$ $\mathrm{s}^{-1}$ estimated in the irrigation depths of $120 \%$ ETo), and a linear increasing behavior was

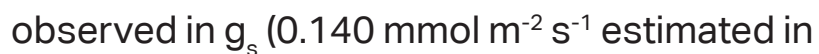
the irrigation depths of $120 \% \mathrm{ETo})$. 
Table 1

Gas exchange of BRS Massai and BRS Tamani weeds during the dry period, under irrigation depths of 30; $60 ; 90$ and $120 \%$ of the reference evapotranspiration (\%ETo)

\begin{tabular}{|c|c|c|c|c|c|c|c|c|}
\hline \multirow{3}{*}{ Grasses } & \multicolumn{4}{|c|}{ Irrigation depths (\% ETo) } & \multirow{3}{*}{ Mean } & \multirow{3}{*}{ CV (\%) } & \multicolumn{2}{|c|}{ P-value } \\
\hline & 30 & 60 & 90 & 120 & & & \multirow{2}{*}{ G } & \multirow{2}{*}{$\mathrm{G} \times \mathrm{D}$} \\
\hline & \multicolumn{4}{|c|}{ Leaf temperature $\left(\mathrm{LT} ;{ }^{\circ} \mathrm{C}\right)$} & & & & \\
\hline Massai & 45.70 & 45.50 & 40.60 & 43.80 & 43.90 & 354 & 108 & 262 \\
\hline Tamani & 45.90 & 44.60 & 44.30 & 43.40 & 44.50 & 0.04 & 1.00 & 2.02 \\
\hline \multicolumn{9}{|c|}{ Equation (effect of irrigation depths) $=49.00-0.111667 x+0.000537 x^{2} ; R^{2}=0.76$} \\
\hline \multicolumn{9}{|c|}{ Internal concentration of $\mathrm{CO}_{2}(\mathrm{Ci} ; \mathrm{ppm})$} \\
\hline Massai & 107.00 & 46.00 & 103.00 & 84.60 & $85.1 \mathrm{a}$ & \multirow{2}{*}{22.31} & \multirow{2}{*}{ * } & \multirow{2}{*}{9.00} \\
\hline Tamani & 27.30 & 14.00 & 93.60 & 96.00 & $57.7 b$ & & & \\
\hline \multicolumn{9}{|c|}{ Equation (effect of irrigation depths) $=73.4583-0.755833 x+0.008102 x^{2} ; R^{2}=0.41$} \\
\hline \multicolumn{9}{|c|}{ Leaf transpiration rate $\left(\mathrm{E} ; \mathrm{mmol} \mathrm{m}^{-2} \mathrm{~s}^{-1}\right)$} \\
\hline Massai & 0.18 & 3.15 & 4.55 & 6.22 & 3.52 & \multirow{2}{*}{33.48} & \multirow{2}{*}{0.25} & \multirow{2}{*}{0.69} \\
\hline Tamani & 0.36 & 2.97 & 5.99 & 5.78 & 3.77 & & & \\
\hline \multicolumn{4}{|c|}{ Equation (effect of irrigation depths) $=$} & \multicolumn{5}{|c|}{$-3.77291+0.15056 x-0.00057 x^{2} ; R^{2}=0.99$} \\
\hline \multicolumn{9}{|c|}{ Stomatic conductance $\left(g_{s^{\prime}} \mathrm{mol} \mathrm{m}^{-2} \mathrm{~s}^{-1}\right)$} \\
\hline Massai & 0.016 & 0.046 & 0.113 & 0.136 & 0.078 & \multirow{2}{*}{40.20} & \multirow{2}{*}{0.34} & \multirow{2}{*}{0.07} \\
\hline Tamani & 0.016 & 0.046 & 0.120 & 0.126 & 0.077 & & & \\
\hline \multicolumn{9}{|c|}{ Equation (effect of irrigation depths) $=-0.025833+0.001383 x ; R^{2}=0.94$} \\
\hline \multicolumn{9}{|c|}{ Leaf photosynthesis rate $\left(A ; \mu \mathrm{mol} \mathrm{m}{ }^{-2} \mathrm{~s}^{-1}\right)$} \\
\hline Massai & 0.56 & 9.07 & 15.97 & 19.01 & 11.15 & \multirow{2}{*}{33.84} & \multirow{2}{*}{0.08} & \multirow{2}{*}{0.16} \\
\hline Tamani & 0.68 & 10.04 & 16.51 & 17.16 & 11.10 & & & \\
\hline
\end{tabular}

Equation (effect of irrigation depths) $=-12.512+0.492544 x-0.001970 x^{2} ; R^{2}=0.99$

Averages followed by different letters differ $(P<0.05)$ by the Tukey test at the $5 \%$ probability level.

In general, the LT of grasses decreased as water availability to plants increased. In a growing plant cell, the forces generated by the turgor cause pressure on the cell wall, resulting in loosening and consequently in increased water content in the cell's protoplasm, even in those that have already stopped growing, which rapidly increases water potential (Taiz \& Ziegler, 2017). This explains the decrease in the leaf temperature of the grasses under larger water regimes, since the greater volume of water in the cellular content is favored by the high specific heat of the water regulating the heating. Meanwhile, the transpiration process causes cooling without damaging the plant. Thus, the specific heat of the water ensures significant temperature stability for plants with plant tissues made up of a large proportion of water.

With regard to the effect of the irrigation levels on $\mathrm{Ci}$, lower concentrations of carbon dioxide under the lowest water regimes are not associated with $\mathrm{CO}_{2}$ consumption for the photosynthetic process. Rather, this is 
the result of stomatal closure to minimize water loss by the grass associated with the low stomatal conductance of 0.016 and 0.046 mmol m${ }^{-2} \mathrm{~s}^{-1}$ under the 30 and $60 \%$ ETo regimes, respectively. The increase in water supply in $E, g_{s^{\prime}}$ and $A$ was accompanied by an increase in the physiological parameters, showing a potential response to irrigation of both tropical grasses.
Grasses and irrigation depths only affected gas exchange in $\mathrm{Ci}$ and during the dry/ rainy transition period (Table 2 ). With regard to the effect of irrigation depths, $E, g_{s^{\prime}}$ and $A$ showed a quadratic behavior with a maximum point of $3.59 \mathrm{~mol} \mathrm{~m}^{-2} \mathrm{~s}^{-1}, 0.112 \mathrm{mmol} \mathrm{m}^{-2} \mathrm{~s}^{-1}$, and $14.45 \mu \mathrm{mol} \mathrm{m}^{-2} \mathrm{~s}^{-1}$ estimated in irrigation depths of $120 \%$ ETo, respectively. The LT showed a quadratic behavior with a minimum point of $40.3^{\circ} \mathrm{C}$ and irrigation depth of $114 \%$ ETo.

\section{Table 2}

Gas exchange of BRS Massai and BRS Tamani weeds during the dry/rainy transition period, under irrigation depths of $30 ; 60 ; 90$ and $120 \%$ of the reference evapotranspiration (\%ETo)

\begin{tabular}{|c|c|c|c|c|c|c|c|c|}
\hline \multirow{3}{*}{ Grasses } & \multicolumn{4}{|c|}{ Irrigation depths (\% ETo) } & \multirow{3}{*}{ Mean } & \multirow{3}{*}{ CV (\%) } & \multicolumn{2}{|c|}{ P-value } \\
\hline & 30 & 60 & 90 & 120 & & & C & $\mathrm{C} \times \mathrm{D}$ \\
\hline & \multicolumn{4}{|c|}{ Leaf temperature $\left(\mathrm{LT} ;{ }^{\circ} \mathrm{C}\right)$} & & & $\vec{J}$ & D \\
\hline Massai & 41.50 & 40.60 & 39.20 & 40.90 & 40.50 & \multirow{2}{*}{4.74} & \multirow{2}{*}{0.26} & \multirow{2}{*}{0.94} \\
\hline Tamani & 43.60 & 40.10 & 40.40 & 39.70 & 40.90 & & & \\
\hline \multicolumn{9}{|c|}{ Equation (effect of irrigation depths) $=45.9120-0.134694 x+0.000736 x^{2} ; R^{2}=0.99$} \\
\hline \multicolumn{9}{|c|}{ Internal concentration of $\mathrm{CO}_{2}(\mathrm{Ci} ; \mathrm{ppm})$} \\
\hline Massai & 29.30 & 96.30 & 105.30 & 120.30 & 87.30 & \multirow{2}{*}{15.68} & \multirow{2}{*}{3.87} & \multirow{2}{*}{ * } \\
\hline Tamani & 44.00 & 70.60 & 78.00 & 117.00 & 77.40 & & & \\
\hline \multicolumn{9}{|c|}{ Leaf transpiration rate $\left(\mathrm{E} ; \mathrm{mmol} \mathrm{m} \mathrm{m}^{-2} \mathrm{~s}^{-1}\right)$} \\
\hline Massai & 0.11 & 1.59 & 2.98 & 3.65 & 2.08 & \multirow{2}{*}{0.11} & \multirow{2}{*}{1.59} & \multirow{2}{*}{2.98} \\
\hline Tamani & 0.58 & 1.99 & 3.50 & 3.43 & 2.37 & & & \\
\hline \multicolumn{9}{|c|}{ Equation (effect of irrigation depths) $=-1.9500+0.084267 x-0.000317 x^{2} ; R^{2}=0.98$} \\
\hline \multicolumn{9}{|c|}{ Stomatic conductance $\left(\mathrm{g}_{\mathrm{s}^{\prime}} \mathrm{mol} \mathrm{m}^{-2} \mathrm{~s}^{-1}\right)$} \\
\hline Massai & 0.01 & 0.03 & 0.09 & 0.10 & 0.06 & \multirow{2}{*}{29.96} & \multirow{2}{*}{0.90} & \multirow{2}{*}{0.10} \\
\hline Tamani & 0.01 & 0.05 & 0.10 & 0.11 & 0.06 & & & \\
\hline \multicolumn{9}{|c|}{ Equation (effect of irrigation depths) $=-0.04375+0.00190 x-0.000005 x^{2} ; R^{2}=0.97$} \\
\hline \multicolumn{9}{|c|}{ Leaf photosynthesis rate $\left(A ; \mu \mathrm{mol} \mathrm{m} \mathrm{m}^{-2} \mathrm{~s}^{-1}\right)$} \\
\hline Massai & 0.91 & 6.42 & 13.12 & 14.25 & 8.67 & \multirow{2}{*}{25.21} & \multirow{2}{*}{1.85} & \multirow{2}{*}{0.34} \\
\hline Tamani & 2.57 & 8.90 & 14.41 & 14.05 & 9.98 & & & \\
\hline
\end{tabular}

Averages followed by different letters differ $(P<0.05)$ by the Tukey test at the $5 \%$ probability level. 
During the dry/rainy transition period, more precisely on the day of measuring gas exchange, a decrease of $0.4^{\circ} \mathrm{C}$ in air temperature, a decrease of $62.5 \%$ in solar radiation, and an increase of $7.6 \%$ in the relative humidity of the air were observed compared to the same one-time measurement during the dry period. Moreover, there was a reduction of 22.2 and $26.6 \%$ in solar radiation $\left(\mathrm{Mj} \mathrm{m}^{-2}\right.$ ) and insolation (hours day ${ }^{-1}$ ) in the ten days preceding the reading of gas exchanges in the transition period. Moreover, there was an increase of $3.2 \%$ in the relative air humidity compared to the same period preceding daily gas exchange in the dry season. These changes in climatic conditions caused different responses in the physiological parameters of the BRS Massai and BRS Tamani grasses, such as the reduction of $7.0 \%, 10.4 \%, 6.2 \%$, and $7.6 \%$ in leaf temperature under $30 \%, 60 \%$, $90 \%$, and $120 \%$ ETo regimes, respectively.

The rates of transpiration and leaf photosynthesis and stomatal conductance changed when compared to the dry period. The rate of leaf transpiration decreased $41.5 \%$, $38.5 \%$, and $41.0 \%$ and increased $21.7 \%$ in the $60 \%, 90 \%, 120 \%$, and $30 \%$ ETo regimes, respectively. The increase in the rate of leaf transpiration of grasses under the $30 \%$ ETo regime may be associated with a higher rate of leaf elongation at the $95 \%$ level of confidence, significantly increasing the transpiration leaf surface. It is worth emphasizing that the gas exchanges were made in a timely manner and that the increase in the leaf elongation rate corresponds to the entire growth period.

The rate of leaf photosynthesis decreased by $19.8 \%, 15.2 \%$, and $21.7 \%$ under the $60 \%, 90 \%$, and $120 \%$ ETo regimes, respectively, while an increase of $64.4 \%$ was observed in grasses under the $30 \%$ ETo regime. The increase in the photosynthetic rate in the $30 \%$ ETo regime can be explained by the rapid elongation and emergence of new leaves, which results from the better climatic conditions observed in the period, favoring water retention in the soil. This process may result from the rapid mobilization of organic reserves after the dry period, which can be seen by the low production of biomass of leaf blade in the previous period (Table 3), leaving the plants in a latent state, when they keep their organic reserves in stock for mobilization in favorable environmental conditions for production. Similar behavior was observed for stomatal conductance of the cultivars BRS Massai and BRS Tamani, with decreases of $28.1 ; 6.5 ; 18.4$, and $17.5 \%$ under $30,60,90$ and $120 \%$ ETo in relation to the same period in the dry season. 
Table 3

Biomass flow of BRS Massai and BRS Tamani weeds during the dry period, under irrigation depths of 30 , $60,90,120 \%$ of reference evapotranspiration (\%ETo)

\begin{tabular}{|c|c|c|c|c|c|c|c|c|}
\hline \multirow{3}{*}{ Grasses } & \multicolumn{4}{|c|}{ Irrigation depths (\% ETo) } & \multirow{3}{*}{ Mean } & \multirow{3}{*}{ CV (\%) } & \multicolumn{2}{|c|}{ P-value } \\
\hline & 30 & 60 & 90 & 120 & & & G & $G \times D$ \\
\hline & \multicolumn{4}{|c|}{ Rate of leaf elongation (cm tiller ${ }^{-1}$ day $^{-1}$ ) } & & & 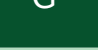 & D. \\
\hline \multirow{2}{*}{$\begin{array}{l}\text { Massai } \\
\text { Tamani }\end{array}$} & 0.09 & 0.57 & 0.94 & 1.37 & 0.74 & \multirow{2}{*}{46.40} & \multirow{2}{*}{1.72} & \multirow{2}{*}{0.66} \\
\hline & 0.13 & 0.56 & 1.20 & 1.94 & 0.96 & & & \\
\hline \multicolumn{9}{|c|}{ Equation (effect of irrigation depths) $=-0.4270+0.017092 x ; R^{2}=0.99$} \\
\hline \multicolumn{9}{|c|}{ Rate of stems elongation ( $\mathrm{cm}$ tiller ${ }^{-1}$ day $^{-1}$ ) } \\
\hline Massai & 0.000 & 0.006 & 0.015 & 0.013 & $0.008 b$ & \multirow{2}{*}{64.61} & \multirow{2}{*}{ * } & \multirow{2}{*}{0.54} \\
\hline Tamani & 0.011 & 0.013 & 0.021 & 0.031 & $0.019 a$ & & & \\
\hline \multicolumn{9}{|c|}{ Equation (effect of irrigation depths) $=-0.000417+0.000194 x ; R^{2}=0.98$} \\
\hline \multicolumn{9}{|c|}{ Leaf senescence $\left(\mathrm{cm}\right.$ tiller-1 day $^{-1}$ ) } \\
\hline Massai & 0.16 & 0.11 & 0.13 & 0.13 & $0.13 b$ & \multirow{2}{*}{73.89} & \multirow{2}{*}{ * } & \multirow{2}{*}{1.23} \\
\hline Tamani & 0.25 & 0.24 & 0.42 & 0.60 & $0.38 a$ & & & \\
\hline \multicolumn{9}{|c|}{ Equation (effect of irrigation depths) $=-0.114167+0.001932 x ; R^{2}=0.79$} \\
\hline \multicolumn{9}{|c|}{ Phyllochron (days) } \\
\hline Massai & 16.60 & 13.10 & 9.80 & 8.20 & 11.80 & \multirow{2}{*}{25.36} & \multirow{2}{*}{1.32} & \multirow{2}{*}{0.38} \\
\hline Tamani & 18.90 & 12.40 & 12.00 & 9.70 & 13.20 & & & \\
\hline
\end{tabular}

Averages followed by different letters differ $(P<0.05)$ by the Tukey test at the $5 \%$ probability level.

With regard to $\mathrm{Ci}$, there was a quadratic behavior with a maximum point in massai grass and a minimum point in tamani grass, with the highest and lowest concentrations of $\mathrm{CO}_{2}(119$ and $48 \mathrm{ppm}$ ) observed in the leaf mesophyll estimated in the irrigation levels of $107 \%$ and $35 \%$ ETo, respectively (Figure 3). The lower $\mathrm{Ci}$ in the leaf mesophyll of tamani grass results from the higher uptake by carboxylate enzymes, resulting in a higher photosynthetic rate. However, these effects were higher under 60 and 90\% ETo, with Tamani grass showing lower mean values than Massai grass $(23.3 \%$ and $25.5 \%$, respectively).

Therewasno interaction effect between grass and irrigation depth for biomass flow during the dry period (Table 3). For the isolated effect of grass, tamani grass presented higher RSE and LS. Although significant differences were found for the variables RSE and LS, these absolute values are insignificant, with mean values below 0.1 and $1.0 \mathrm{~cm}$ tiller ${ }^{-1}$ day $^{-1}$, respectively. Thus, it can be inferred that under these conditions the rate of elongation of the stems and leaf senescence was minimal for the two forages. Regarding the isolated effect of irrigation depth, there was an increasing linear effect for the variables RLE, RSE and LS and quadratic effect with minimum point for the phyllochron variable, with 1.62, 0.022 and $0.11 \mathrm{~cm}$ tiller $^{-1}$ day $^{-1}$ and 9.0 days, respectively, estimated under the regimen of $120 \%$ of ETo. 


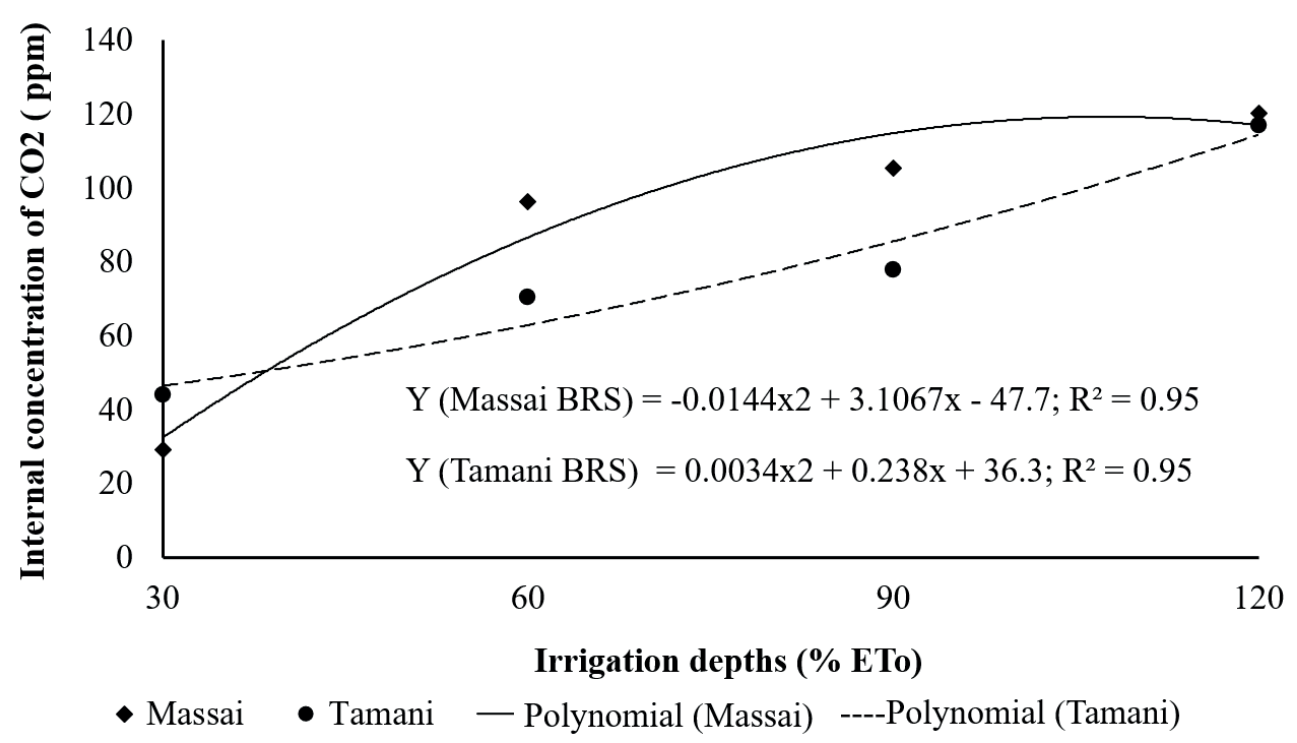

Figure 3. Internal $\mathrm{CO}_{2}$ (Ci) concentration of BRS Massai and BRS Tamani weeds submitted to irrigation depths (30;60; 90 and $120 \%$ of ETo), during the dry/rainy transition.

Regarding the RLE variable, there were increases of $85.6 \%$ in the treatment of $60 \%$ in relation to that of $30 \%$ of ETo, $46.8 \%$ in the treatment of $90 \%$ in relation to $60 \%$ of ETo and $31.5 \%$ in the treatment of $90 \%$ in relation to that of $120 \%$ of ETo, concluding that the greatest increases in RLE are found in a way that is in addition to irrigation regimes. Inverse behavior was verified for the phylochron variable, with a reduction of the variable starting from 17.7 days for the regimen of $30 \%$ of ETo at 9.0 days for the treatment of $120 \%$ of ETo. The phyllochron verified under the highest irrigation regimes corroborate those found by Gomide and Gomide (2000) when they evaluated the leaf appearance rate of four Megathyrsus maximus cultivars (Sin. Panicum maximum).

Similarly, to what occurred in the dry period, there was no interaction $(P>0.05)$ between grass and irrigation depth during the dry/rainy transition period (Table 4). Regarding the isolated effect of grass, Tamani grass obtained the highest RLE, RSE and LS.

For the isolated effect of irrigation depth, a decreasing linear effect was observed for the variable RLE and quadratic with maximum and minimum point for RSE and LS, respectively with the highest averages of 1.13 , 0.13 and $0.14 \mathrm{~cm}$ tiller day ${ }^{-1}$ estimated in the slides of $120 ; 69$ and $68 \%$ of ETo, respectively. In the period in question, the high precipitation occurred in the period $(100.6 \mathrm{~mm})$, which is equivalent to a supplementation of 5.33 liters of water pot ${ }^{-1}$, resulted in inverse behavior for RLE if equated to the dry period. As a result, RLE under the 30 schemes; 60 and $90 \%$ of ETo had increases of $95 ; 59.6$ and $14 \%$ while grasses under the regime of $120 \%$ of ETo had decreases of $30.2 \%$. 
Table 4

Biomass flow of BRS Massai and BRS Tamani weeds during the dry/rainy transition period, under irrigation depths of $30,60,90,120 \%$ of reference evapotranspiration (\%ETo)

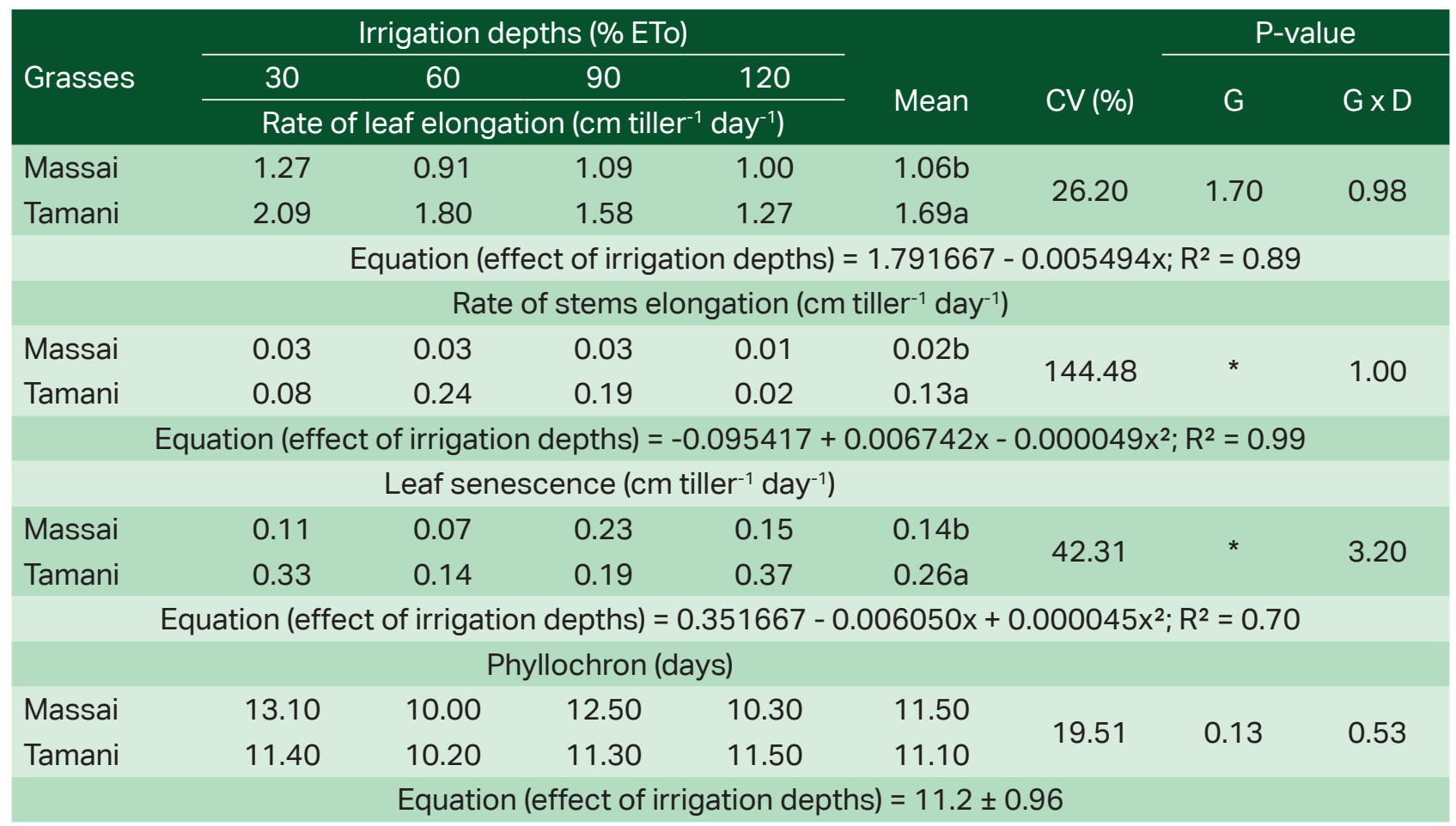

Averages followed by different letters differ $(P<0.05)$ by the Tukey test at the $5 \%$ probability level.

The increase in RLE can be explained by the recovery of morphophysiological status of grasses that came under the lowest water regimes, mainly by the probable mobilization of organic reserves, provided by better water supply and better temperature conditions (average reduction of $1.8{ }^{\circ} \mathrm{C}$ ) and relative humidity (increase of 17.8\%) compared to the dry season. On the other hand, the grasses under the regimes of $120 \%$ of The ETo presented a reduction in RLE, caused, in the meantime, by the excess of water coming from the precipitations, causing prolonged soaking of the roots and affecting the gas exchange. Plants susceptible to water stress by soil soaking exhibit a series of changes in their physiology, such as reduction in root conductance, stomatic closure and decrease in photosynthetic rate, causing a significant reduction in productivity (Araújo et al., 2010; Santos, Guimarães, Klein, Fioreze, \& Macedo, 2012), in addition to chlorosis and reduction in vegetative growth.

The process of stretching the stems occurred mainly under the regimes of 60 and $90 \%$ of ETo for the emission of the inflorescence, however there was not enough time for the complete expansion of the panicle, due to this process having started late and the time of cutting.

There was interaction $(P<0.05)$ between grasses and irrigation depths on GLBB and PDT during the dry period (Table 5). Regarding 
the isolated effect of irrigation depths, an increasing linear effect was observed for the variable dead material, NLL and WUEGFB with

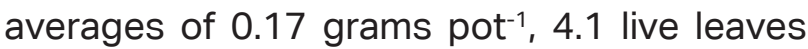

per tiller and $0.016 \mathrm{~g} \mathrm{DM}^{-1} \mathrm{~mm}^{-1}$, respectively, and, decreasing to the angle variable with an average of $36.3^{\circ}$ angle of the stems, estimated in the depths of $120 \%$ of ETo, respectively.

\section{Table 5}

Structural characteristics, biomass components and water use efficiency of BRS Massai and BRS Tamani weeds during the dry period, under irrigation depths of 30; 60; 90 and $120 \%$ of the reference evapotranspiration (\%ETo)

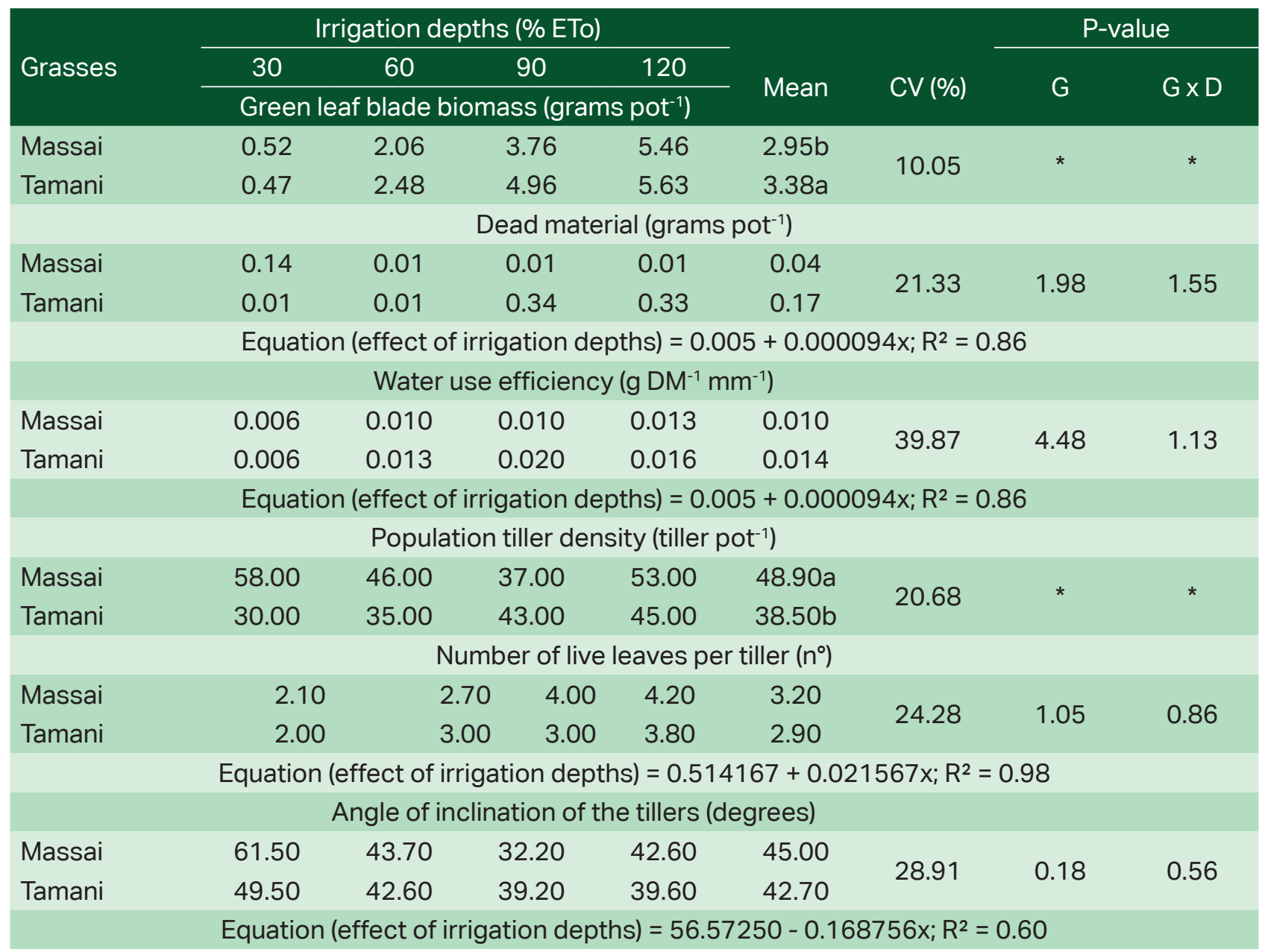

Averages followed by different letters differ $(P<0.05)$ by the Tukey test at the $5 \%$ probability level.

For the variable GLBB, the largest increments were achieved with the treatments best supplied hydric (Figure 4). Quadratic behavior was verified with increasing means for BRS Massai and BRS Tamani weeds of 0.52 and $0.36 ; 2.09$ and 2.82; 3.74 and 4.62; 
and 5.47 and 5.75 grams pot $^{-1}$, respectively, estimated in the depths of 30; 60; 90 and $120 \%$ of ETo. Tamani grass, in general, presented higher production of GLBB, especially in treatments of 60 and $90 \%$ of ETo, with an increase, in percentage points, of 26.2 and $19.2 \%$ in relation to Massai grass, much due to the higher leaf width. However, it is worth noting that the slight decline in the production of GLBB of tamani grass under the regime of $120 \%$ of ETo, may result in low tolerance of this forage to a higher level of water in the soil, even for brief periods, presenting chlorotic aspect in some leaf blades; or be associated with low nutrient availability due to leaching losses in the soil.
The number of live leaves of tiller, despite being a genetically conditioned structural characteristic, its expression is dependent on environmental conditions such as water and nutrient availability (Duarte, Paiva, Fernandes, Biserra, \& Fleitas, 2019). Thus, the increase in leaf elongation rate due to the better availability of water in the soil, provided, in a linear way, an increase in the number of leaves. However, the height of Tamani grass was not linearly correlated with the increase in the number of leaves. As already reported above, the edaphic factors and the largest water regimes seem to have disadvantaged tamani grass, causing changes in canopy architecture as an increase in the angle of the inclination of the tillers and consequent decrease in height, presenting more prostrate leaves.

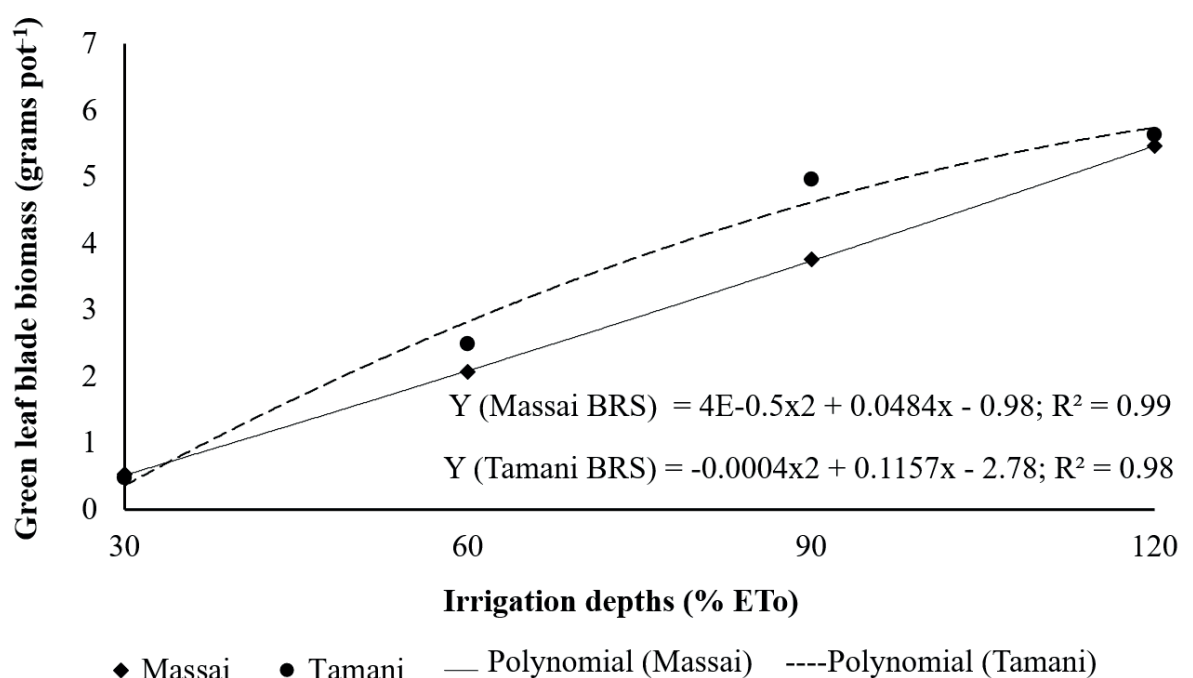

Figure 4. Green leaf blade biomass (GLBB) of BRS Massai and BRS Tamani weeds submitted to irrigation depths (30; 60; 90 and 120\% of ETo) during the dry period. 
Regarding the variable population density of tiller (PDT), although the grasses presented different behaviors (quadratic with a minimum point of 39 tiller pot $^{-1}$ for massai and quadratic grass with a maximum point of 46 tiller pot ${ }^{-1}$ for Tamani grass estimated in the depth of 80 and $120 \%$ of ETo, in this order). The number of tillers for both grasses in all treatments with irrigation depths stabilized already in the establishment phase, with no significant death and emergence of new tillers for the following two growth phases (Figure 5).

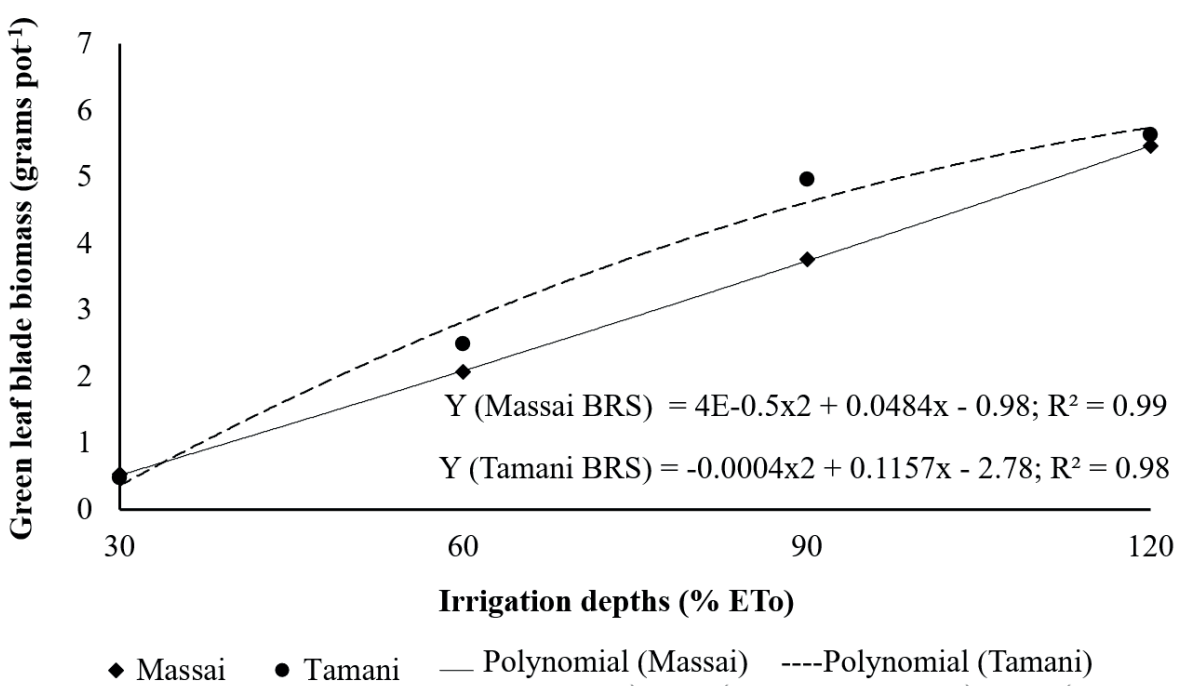

Figure 5. Population density of tillers (PDT) of BRS Massai and BRS Tamani weeds submitted to irrigation depths (30; 60; 90 and 120\% ETo) during the dry season.

The stabilization of the number of tillers BRS Massai and BRS Tamani weeds can be attributed to the phenomenon of plant rosette, which caused mutual shading of leaves and basilar buds, limiting light in qualitied and quantitate terms that reaches the base of the stem, inhibiting the emergence of new planters. Light intensity can be considered the most limiting environmental factor in the dynamics of tiller in grasses. Thus, under strong radiation, there is the stimulus in the process of news tillers, in a contrary situation, the growth of axillary and basal gems is suppressed (Gomide \& Gomide, 2000).
Thinning for the permanence of three tillers per pot, associated with high incident radiation and the growth potential of these Megathyrsus maximus cultivars, may have favored the rosette of the tillers. It was observed that, in each of the three seedlings, there was the emergence of new seedlings of the stem base of the main tiller. Thus, the large number of tillers $(16.3 \pm 3.03$ and $12.8 \pm 2.33$ for BRS Massai and BRS Tamani weeds, in this order) arising from a common point, promoted the repulsion of stems from the center to the end, impelling at a smaller angle $\left(5.06^{\circ} \pm 0.05\right.$ for each treatment of the ETo regimen), causing the form of "rosette" of the clump. 
There was interaction $(\mathrm{P}<0.05)$ between grasses and irrigation depths for the variables green stem biomass and leaf blade/ stem ratio during the dry period (Table 6). For the isolated grass effect, Tamani grass differed significantly from Massai grass in relation to dead forage biomass (DM) and population density of tiller (PDT). With reference to the isolated effect of irrigation depth, a quadratic effect with maximum point for the variable PDT was observed, of minimum for the variables DM, WUEGFB and Angle of inclination of the tillers, with averages of $40 \mathrm{~g} \mathrm{pot}^{-1}, 0.01 \mathrm{~g} \mathrm{pot}^{-1}$, $0.016 \mathrm{~g} \mathrm{DM}^{-1} \mathrm{~mm}^{-1}$ and $65.2^{\circ}$ angle of the rods estimated in the depth of $70,85,115$ and $75 \%$ of ETo, respectively.

\section{Table 6}

Structural characteristics, biomass components and water use efficiency of BRS Massai and BRS Tamani weeds during the dry/rainy transition period, under irrigation depths of $30 ; 60 ; 90$ and $120 \%$ of the reference evapotranspiration (\%ETo)

\begin{tabular}{|c|c|c|c|c|c|c|c|c|}
\hline \multirow{3}{*}{ Grasses } & \multicolumn{4}{|c|}{ Irrigation depths (\% ETo) } & \multirow{3}{*}{ Mean } & \multirow{3}{*}{ CV (\%) } & \multicolumn{2}{|c|}{ P-value } \\
\hline & 30 & 60 & 90 & 120 & & & $c$ & 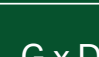 \\
\hline & \multicolumn{4}{|c|}{ Green leaf blade biomass (grams pot ${ }^{-1}$ ) } & & & 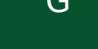 & $3 \times 5$ \\
\hline Massai & 7.30 & 5.56 & 7.40 & 7.30 & 6.89 & \multirow{2}{*}{15.16} & \multirow{2}{*}{0.11} & \multirow{2}{*}{0.74} \\
\hline Tamani & 5.96 & 6.60 & 7.66 & 6.76 & 6.75 & & & \\
\hline \multicolumn{9}{|c|}{ Equation (effect of irrigation depths) $=6.77 \pm 0.63$} \\
\hline \multicolumn{9}{|c|}{ Dead material (grams pot ${ }^{-1}$ ) } \\
\hline Massai & 0.01 & 0.01 & 0.01 & 0.01 & $0.01 b$ & \multirow{2}{*}{143.57} & \multirow{2}{*}{ * } & \multirow{2}{*}{4.10} \\
\hline Tamani & 0.53 & 0.01 & 0.04 & 0.17 & $0.19 a$ & & & \\
\hline \multicolumn{9}{|c|}{ Equation (effect of irrigation depths) $=0.000090^{*}-0.015303^{*}+0.63875 ; R^{2}=0.94$} \\
\hline \multicolumn{9}{|c|}{ Water use efficiency $\left(\mathrm{g} \mathrm{DM}^{-1} \mathrm{~mm}^{-1}\right)$} \\
\hline Massai & 0.083 & 0.033 & 0.030 & 0.020 & 0.041 & \multirow{2}{*}{13.09} & \multirow{2}{*}{0.58} & \multirow{2}{*}{3.69} \\
\hline Tamani & 0.070 & 0.040 & 0.030 & 0.020 & 0.040 & & & \\
\hline \multicolumn{9}{|c|}{ Equation (effect of irrigation depths) $=0.000008^{*}-0.001839^{*}+0.12250 ; R^{2}=0.96$} \\
\hline \multicolumn{9}{|c|}{ Population tiller density (tiller pot ${ }^{-1}$ ) } \\
\hline Massai & 57.00 & 46.00 & 37.00 & 53.00 & $48.60 a$ & \multirow[t]{2}{*}{21.62} & * & \multirow[t]{2}{*}{2.52} \\
\hline Tamani & 33.00 & 38.00 & 43.00 & 45.00 & $39.80 b$ & & & \\
\hline \multicolumn{9}{|c|}{ Equation (effect of irrigation depths) $=0.003519^{*}-0.492222^{*}+57.416667 ; R^{2}=0.90$} \\
\hline \multicolumn{9}{|c|}{ Number of live leaves per tiller $\left(n^{\circ}\right)$} \\
\hline Massai & 2.70 & 3.60 & 2.80 & 3.30 & 3.10 & \multirow{2}{*}{18.73} & \multirow{2}{*}{0.59} & \multirow{2}{*}{1.79} \\
\hline Tamani & 2.90 & 3.30 & 3.20 & 2.30 & 2.90 & & & \\
\hline \multicolumn{9}{|c|}{ Equation (effect of irrigation depths) $=3.0 \pm 0.28$} \\
\hline \multicolumn{9}{|c|}{ Angle of inclination of the tillers (degrees) } \\
\hline Massai & 57.50 & 55.60 & 61.80 & 65.80 & 60.10 & \multirow{2}{*}{25.89} & \multirow{2}{*}{0.11} & 197 \\
\hline Tamani & 52.70 & 75.20 & 63.90 & 45.90 & 59.40 & & & 1.01 \\
\hline
\end{tabular}

Averages followed by different letters differ $(P<0.05)$ by the Tukey test at the $5 \%$ probability level. 
The WUEGFB was negatively influenced by the increase of irrigation depths. Contrary to what was observed in the dry season, where the highest WUEGFB was contemplated with the highest water availability, in the dry/rainy transition period, the incident precipitation of 100.6 millimeters favored inverse behavior for this variable. Thus, if equated to the dry period, the WUEGFB had an estimated increase of $90.5,72.5,40.9$ and $5.8 \%$ under the regimes of 30; $60 ; 90$ and $120 \%$ of ETo, respectively (Table 6). The higher efficiency in water use presented in the regimens of 30 and $60 \%$ of ETo is a function of the probable mobilization of the organic reserves of the grasses that produced little biomass in the previous period, resulting in a higher rate of leaf elongation and resulting from gains in biomass.

The PDT, compared to dry period, showed insignificant increase and deaths of tillers of both grasses with the increase of water supplement caused by precipitation. This fact is possibly due to the large number of superimposed stems, mutual shading of leaves and/or low availability of soil nutrients causing stabilization of the number of plants. The angle of inclination of the tillers, in turn, was influenced by the beginning of the reproductive period of Tamani grass, presenting an increase in the mean angle estimated at 17.7 and $22.8^{\circ}$ in the regimens of 60 and $90 \%$ of ETo, respectively, in relation to the same treatment in the dry season.

\section{Conclusions}

According to estimates, by growing forage in field pots, BRS massai and BRS Tamani grasses are well adaptable to texture soil conditions with more sand and climatic in the Brazilian Semiarid region. The minimum irrigation depth of $30 \%$ of ETo allows the maintenance of BRS Massai and BRS Tamani grasses in the dry period without compromising the vigor and number of plants with the arrival of the rainy period. The maximum irrigation depth of $90 \%$ of The ETo provided the best morphological and structural responses of the grasses evaluated, especially Tamani grass.

\section{References}

Araújo, S. A. C., Vasquez, H. M., Campostrini, E., Netto, A. T., Deminicis, B. B., \& Lima, E. S. (2010). Características fotossintéticas de genótipos de capim-elefante anão (Pennisetum purpureum Schum.), em estresse hídrico. Acta Scientiarum: Animal Sciences, 32(1), 1-7. doi: 10.4025/ actascianimsci.v32i1. 8961

Barros, J. S., Meirelles, P. R. L., Gomes, V. C., Pariz, C. M., Fachiolli, D. F., Santana, E. A. R.,... Souza, D. M. (2019). Valor nutritivo do capim-xaraés em três intensidades luminosas. Arquivo Brasileiro de Medicina Veterinária e Zootecnia, 71(5), 1703-1711. doi: 10.1590/1678-4162-10801

Dantas, G. F., Faria, R. T., Santos, G. O., Dalri, A. B., \& Palaretti, L. F. (2016). Produtividade e qualidade da brachiaria irrigada no outono/inverno. Engenharia Agrícola, 36(3), 469-481. doi: 10.1590/1809-4430Eng.Agric.v36n3p469-481/2016

Duarte, C. F. D., Paiva, L. M., Fernandes, H. J., Biserra, T. T., \& Fleitas, A. C. (2019). Capim tropical manejado sob lotação intermitente, submetido a fontes de fósforo com diferentes solubilidades, associados ou não à adubação com nitrogênio. Ciência Animal Brasileira, 20(1), 1-15. doi: 10.1590/10 89-6891v20e47692 
Gomes, G. M. F., Candido, M. J. D., Lopes, M. N., Maranhão, T. D., Andrade, D. R., Costa, J. F. M.,... Neiva, J. N. M. (2018). Chemical composition of cactus pear cladodes under different fertilization and harvesting managements. Pesquisa Agropecuária Brasileira, 53(2), 221-228. doi: 10.1590/ s0100-204x 2018000200011

Gomide, C. A. M., \& Gomide, J. A. (2000). Morfogênese de cultivares de Panicum maximum Jacq. Revista Brasileira de Zootecnia, 29(2), 341-348. doi: 10.1590/ S1516-35982000000200004

Funceme. Fundação Cearense de Meteorologia e Recursos Hídricos. Available on: http:// www.funceme.br

Maranhão, S. R., Pompeu, R. C. F. F., Souza, H. A., Araújo, R. A., Fontinele, R. G., \& Cândido, M. J. D. (2019). Morphophysiology of buffel grass grown under different water supplies in the dry and dry-rainy seasons. Revista Brasileira de Engenharia Agricola e Ambiental, 23(8), 566-571. doi: 10.1590/1807-1929/agriambi.v23n8 p566-571

Marijuan, P. M., \& Bosch, M. S. (2013). Ecophysiology of invasive plants: osmotic adjustment and antioxidants. Trends in Plant Science, 18(13), 660-666. doi: 10.1016/j.tplants.2013.08.006

Monteiro, J. G., Cruz, F. J. R., Nardin, M. B., \& Santos, D. M. M. (2014). Crescimento e conteúdo de prolina em plântulas de guandu submetidas a estresse osmótico e à putrescina exógena. Pesquisa Agropecuária Brasileira, 49(1), 18-25. doi: 10.1590/S0100-204X2014000100003
Pezzopane, C. G., Santos, P. M., Cruz, P. G., Altoé, J., Ribeiro, F. A., \& Valle, C. B. (2015). Hydric deficiency in genotypes of Brachiaria brizantha. Ciência Rural, 45(5), 871-876. doi: 10.1590/0103-8478 cr20130915

Santos, D., Guimarães, V. F., Klein, J., Fioreze, S. L. \& Macedo, E. K. Jr. (2012). Cultivares de trigo submetidas a déficit hídrico no início do florescimento, em casa de vegetação. Revista Brasileira de Engenharia Agricola e Ambiental, 16(8), 836-842. doi: 10.1590/ S1415-43662012000800004

Santos, P. M., Cruz, P. G., Araujo, L. C., Pezzopane, J. R. M., Valle, C. B., \& Pezzopane, C. G. (2013). Response mechanisms of Brachiaria brizantha cultivars to water deficit stress. Revista Brasileira de Zootecnia, 42(11), 767-773. doi: 10.1590/ S1516-35982013001100001

Santos, H. G., Jacomine, P. K. T., Anjos, L. H. C., Oliveira, V. A., Oliveira, J. B., Coelho, M. R.,... Cunha, T. J. F. (2018). Sistema brasileiro de classificação de solos (5a ed., rev. e ampl.). Brasília: EMBRAPA.

Silva, E.B., Carneiro, M.S.S., Furtado, R. N., Lopes, M. N., \& Braga, M. M. (2020). Composição química do capim BRS Zuri submetido a níveis de salinidade e lâminas de irrigação. Revista Ciência Agronômica, 52(1), 1-10. doi: $10.5935 / 1806-6690.20200016$

Souza, M. T. C., \& Martuscello, J. A. (2017). Produtividade de cultivares forrageiros no nordeste brasileiro. Pubvet, 12(4), 1-9. doi: 10.22256/pubvet.v12n4a70.1-9

Taiz, L., \& Zeiger, E. (2017). Fisiologia vegetal (6a ed.). Porto Alegre: Artmed. 